\title{
Social Media Comments in Triangle of Belonging, Ignorance of Narcissism
}

\author{
Türk G. D. ${ }^{1}$ \\ ${ }^{1}$ Gül Dilek Türk, Adnan Menderes University, (Turkey) \\ e-mail: guldilekturk@yahoo.com
}

\begin{abstract}
As a situation on Social media that is frequently encountered in recent times, comments, which whether or not knowledge about matter of any share/posts on social media that contain criticism, humiliating, judging, lynch are drawn reaction by users. Behind these interpretations there are reasons such as feeling important, feeling unique, being part of a group, narcissism, creating false self, Dunning-Kruger syndrome and the important reason is shifting authority on social media. Users have begun to be more visible and to feel free and the possibility of accessing to everything and everyone easily by means of social media. In this context, the prominent comments on the social media will be selected by using methods of participation and unattended netnography and Vandijk's critical discourse analysis will be examined.
\end{abstract}

Keywords: Social Media, Narcissism, Belonging, Identity, Ignorant Courage.

\section{Introduction}

In the recent period, comments which contain criticizing, judging, lynch even if it has not been knowledge about the matter to every share is made on social media (Twitter, Instagram or Facebook shares, etc.) come to the fore. Social media makes everyone equal. So, people can easily come together in the same place and environment in the virtual world with the people they cannot reach in the physical world. This convenience allows users to easily communicate and interact with people who do not dare to communicate in the physical world, as well as it makes them feel unique, special and a part of the group because of narcissism, false self-creation,

Individuals who are uniformed by modernism and lose their singularity can express their opinions even if they do not have knowledge in response to a question on social media through motivations such as re-feeling, value-seeing (Türk, 2018). Sometimes, as a social entity in social media to enter into a group that he sees itself close to, makes comments in order to belong to that group (Türk, 2017). Because of narcissism some people make these comments to aim to feed and aggrandize own ego by making comment by humiliating and mocking shares by other users.

Social media provides users with access to all types of information, regardless of their socioeconomic status. this shifting authority causes if user has false self and narcissistic tendency judging, lynching without evaluating subject in all its parts. Especially social media gives users anonymously multiple identities. this situation causes users can behave nonethically and immoral. Users can troll for enjoying and start lynch.

In this context, the prominent comments on the social media will be selected by using methods of participation and unattended netnography and Vandijk's critical discourse analysis will be examined. Under theories of Hegel's master-slave dialectic and Dunning-Kruger syndrome, narcissism, selfpsychology. 


\section{Literature}

The self encompasses the essence, personality and ego. Every human being is born with certain characteristics and potentials, which could particularly be benevolent (libido) or malevolent (aggression). From the moment a baby is born, it actualizes an epigenetic epiphany based on its developmental experiences and puts its characteristics into operation. During this physiological and psychological development, its neck muscles become strong enough to hold up its head, and then, its starts to move, crawl and walk. From the sixth month on, it starts to talk, move and break away from its mother's control, allowing it to begin forming the nuclei of the self, resulting in the development of nerve cells and formation of mental records. It interprets the experiences that it records in its mind and makes sense of them and forms subconscious codes.

The baby depends on its mother from the moment it is born until the sixth month, after which, it gains its autonomy and forms its own self. Its desire to use its own will is especially manifested during the complementary food period. It refuses to eat or makes a hand sign to indicate that it wants food or wants to use the spoon itself, which is the sign of its nuclei of the self. If the mother is mentally well, the separation process goes as smoothly as possible and the baby becomes a healthy individual. If the mother is mentally unwell, she does not want to separate from her baby and develops a dependent relationship.

The baby wants act of its own free will as it gains autonomy. From the age of one and a half, it gains individuality both mentally and spiritually. Until this period, it perceives itself as a part of its mother or the mother as its own. It becomes aware of itself from the age of one and a half years. With weaning and toilet training, it becomes fully autonomous and recognizes its own individuality. Thus, the period of personality development, which is referred to by Freud as ego, begins. This period encompasses the construction of the self, involving both the ego (consciousness) and the id (subconscious). The first 18 months are critical for personality development. The ego process triggers the baby' desire to use its own will. If the baby is allowed to act of its own free will, then it can complete the development of self in a healthy way.

The baby's whole life and its relationships with people are affected by this process experienced by it and its mother because the effect of the mother on the baby is $70 \%$, while that of the father and the environment is only $20 \%$ and $10 \%$, respectively. Therefore, the relationship between mother and baby plays a key role in the personal development of latter. The baby's records and subconscious codes make up its character. If this character is in harmony with the baby's innate characteristics, then it can develop its true self. However, if given codes cause it to develop a character that is incompatible with its innate characteristics, then it ends up developing a false self.

If parents provide their children with education that matches their will, they can develop a healthy self and healthy relationships. Dependent mothers who say such manipulative things as "I'm not talking to you because you didn't do this and that" or "what would others say?" prevent their children from becoming independent individuals who make autonomous decisions. Forcing a child who likes doing sports to take an interest in arts or forcing a child who wants to be a lawyer to go to medical school cause them to develop a personality, that is, a false self, that does not match their innate characteristics. The false self leads to an unhappy and unsatisfied life and unhealthy relationships.

Those who develop false selves do not take risks, do not say no and do not like themselves. They are afraid that if they say "no," they will be abandoned, which relates to the relationship between mother and baby. Using the right brain lobe, the baby adopts its mother's gestures. If a baby perceives from its mother's gestures that she is dissatisfied or angry with the way it uses its will, then it will have a fear of abandonment. It will think "I will not be loved if I become myself and act of my own free will," which has a negative effect on its relationships throughout its life.

\section{False Self and Narcissism}

Self-psychology is a psychoanalytic theory developed by Heinz Kohut in 1971. He first addressed the self within ego and developed a theory that explored how one perceived oneself and how one 
developed images of oneself. In 1977, he removed his theory from the self and defined a superstructure as a "core of personality, perceptions and initiatives of the center," which also encompassed the self and ego.

Masterson defines the "true self" as one's self-perception in adulthood in relation to other people that develops in early adolescence when one is psychologically separated from one's parents (2016: 17). According to him, the search for meaning is the expression of one' true self. If one does not develop a healthy self that adapts to social contexts, then one develops a false self, in which one takes refuge to protect oneself instead of experiencing destructive behaviors that lead to feelings of failure, lost hopes, unfulfilled dreams and sorrow and to avoid feeling bad and inadequate and overcoming difficulties. Defined by psychoanalytic theorists as personality disorders, these behavioral patterns prevent people from establishing healthy relationships with oneself and others, resulting in such disorders as narcissism and borderline (Masterson, 2012).

People who cannot form healthy bonds with their parents in early childhood feel neglected, abandoned, unpopular, undesirable, unworthy and inadequate. They develop false selves to avoid confronting those feelings but end up experiencing inner ruptures that result in psychological disorders. Babies whose needs are not met by their parents during the early childhood ( $0-3$ years) learn how to self-sustain (Ozan et al., 2008), and neglect and lack of secure attachment causes disappointment and negative feelings in them leading to the feelings of loneliness, neglect, worthlessness and inadequacy.

One tends to behave differently when one feels anxiety resulting from the conception that "If I become myself, I will be abandoned and If I do what I want to do, others will make me feel worthless and inadequate." Masterson argues that people tend to attribute the feelings of unhappiness and inadequacy to external factors and others but that they are actually caused by internal issues. He also argues that indecisiveness, irrationality and self-righteousness are caused by this behavior disorder (2012 / a: 11). While people with true selves create their own meanings by experiencing them, those with false selves accept what is given to them and use it as a defense against experience (Masterson, 2012 / b: 12). They think that if they develop true selves, they will have to deal with the deep fears that they had to at the age of 0-3 years. Therefore, they believe that false selves protect them and help them feel safe.

Kohut divides the development of the self into three stages and argues that narcissism is mainly due to the feeling of inadequacy in early childhood (1971). To him, insecure mother-child attachment in the first stage ( 0 to 3 years of age) and mother's failure to meet her baby's physiological and psychological needs hurt the self and lay the foundations of narcissism. In the second stage, if the baby is unable to establish a healthy attachment with the mother in the first stage, then it turns to the father to feel excellent, competent and worthy. If the baby manages to establish a healthy relationship with the father, then its self that had been hurt by the mother heals. However, if the baby is unable to establish a healthy relationship with the father and lacks the positive feelings that it needs, it can then use its innate skills to save itself from growing up in an underdeveloped spiritual structure and achieves to develop a true sense of self in the third stage. But (Kohut, 1977) states that at this stage most children hide behind their own personalities and give the impression that they are smarter and more talented than they really are. However, they actually feel inadequate but wear masks to see themselves successful in the world of dreams. However, they do not really want to compete and succeed. They avoid the feelings of jealousy by demeaning the efforts of people who call them for competition or try to prove them unqualified with a destructive fury (Kernberg, 2012). Kohut argues that the main reason for narcissism is parents who fail to satisfy their children's spiritual needs.

Narcissism is a personality disorder. Due to the feelings of inadequacy and weak self, narcissists feel the need to be perceived by others as perfect, unique and indispensable. They develop false selves that they believe everybody finds admirable to suppress the feelings of inadequacy and weak self. Masterson (2006) defines the main characteristics of narcissism as grandiosity, extreme selfinvolvement, lack of empathy, sensitivity to criticism, sense of self-righteousness and an overwhelming need for the admiration and approval of others. Narcissism is the libidinal self-regulation of one's capacity to develop personal standards, ideals and ambitions in order to develop self-esteem, to defend oneself and to perceive oneself as unique due to negative records in early childhood. 
Kohut (1977) states that narcissistic personality disorder is caused by "defects in the structure of the self." There are two types of narcissism: normal and pathological. Normal narcissists feel that they can meet their own and others' expectations and are not affected by criticism because they have high selfconfidence and self-worth and focus on views of themselves and uphold and satisfy their selfconfidence (Akhtar, 1989; Rozenblatt, 2002). Narcissists exert constant effort to continue to be praised and admired, otherwise, they experience a rupture in their false selves and a narcissistic injury. Pathologic narcissists have deeper feelings and more exaggerated behaviors and reactions than normal narcissists. Although they appear not to care about others' thoughts and criticism, they are in fact entirely vulnerable to them (Karaaziz and Atak, 2013). While normal narcissists respond more superficially to criticisms, pathological narcissists feed off of and base their worth on external reactions and criticisms (Rozenblatt, 2002). When normal narcissists cannot get the positive reactions they expect, they feel low, however, it is deeper and more shocking for pathological narcissists. They react more aggressively to conceal their self-perceived weaknesses and negative aspects.

\section{Courage of Ignorance}

Dunning-Kruger syndrome, known as Cahil Cesareti (Courage of Ignorance) in Turkish, is a type of cognitive bias in which people mistakenly assess their cognitive ability as greater than it is. People with this syndrome have become more visible thanks to social media which has provided a sense of freedom and easy access to everything and everyone. These people are made a mockery of or lynched on social media.

Dunning-Kruger Effect was coined in 1999 by then-Cornell psychologists David Dunning and Justin Kruger as a result of a series of experiments on perception bias. They argue that Dunning-Kruger Effect is a delusional sense of superiority and a perceptual illusion by which incompetent people regard themselves as all-knowing about any given subject, even though they have little or no knowledge about it (Dunning \& Kruger, 1999; Schlösser et al., 2013). Those people fail to recognize their inadequacy and lack of knowledge and declare their opinions and even have the courage and confidence to blame the true authorities for lack of knowledge.

David Dunning and Justin Kruger conducted a series of experiments on Cornell University students in 1999 to show how the syndrome emerged and spread. They applied a test to participants to examine self-assessment of logical reasoning skills, grammatical skills and humor. The incompetent participants grossly overestimated their test performance and ability and commented on the test and questions with high self-confidence, and although their scores put them in the 12th percentile, they estimated themselves to be in the 62 nd, showing that the higher the success rate, the lower the selfconfidence. This result indicates that people with Dunning-Kruger syndrome lack the capacity to selfassess.

When people with Dunning-Kruger syndrome have little knowledge about a subject they feel selfconfident and have less self-confidence when they have no knowledge or when their knowledge increases (Poundstone, 2017).

The study shows that people with Dunning-Kruger syndrome fail to recognize their ignorance. However, after some training, they recognize their ignorance and lack of quality. According to Dunning and Kruger, knowledge capacity plays a key role in assessing thirst for knowledge, success and satisfaction, and in determining which rules and strategies to follow. Knowledge capacity also plays an important role not only in social and intellectual fields, but also in many areas ranging from raising children to developing lessons and creating logical arguments in these areas. Developing different solutions and strategies depends on the diversity and foundations of knowledge. If one is ignorant, one makes wrong decisions and acts with great motivation and courage to execute them (Dunning \& Kruger, 1999: 1121). Cognitive psychologists argue that incompetent people lack the ability to know, assess, perceive and control themselves. Dunning and Kruger argue that people who fail to master the rules of grammar lack the ability to construct meaningful and correct sentences and that if they have no knowledge of any subject, they lack the ability to make the right judgments (Dunning \& Kruger, 1999: 1122). Charles Darwin, an evolutionary theorist, argues that ignorance is more reassuring than knowledge and causes people to act with unfounded self-confidence instead of pursuing knowledge 
(1871: 3). Many philosophers also agree that the ignorant assert their claim more courageously, ardently and confidently than the wise.

People with a false perception of superiority ignore their shortcomings, imperfections and negative characteristics and see themselves above average. Since they cannot criticize themselves, they see themselves perfect and judge other people and events very harshly. Similar to Dunning-Kruger syndrome, people who consider themselves superior to others think that they have the right to judge things and others. Incompetent people suffer from a cognitive awareness of themselves, and therefore, exaggerate their own knowledge and skills to judge people and things instead of verifying their own opinions. They are, however, reluctant to assess themselves and to see their shortcomings. Nietzsche uses the term "bildungsphilister" to describe people who read newspapers and imagine themselves to be cultured and educated but lack original instincts and approach events in a dogmatic and cliché manner and are prone to false reactions. While ignorant people tend to see themselves superior, knowledgeable and equipped people are more aware of their shortcomings and imperfections, and therefore, are less self-confident and more questioning and criticize themselves more harshly. This is because they take into account external factors when judging others but take into account their own desires, intentions and efforts when judging themselves. Doing this, they aim to feel special by making their selves that have been standardized and banalized by modernism unique again.

\section{The Shifting Authority on Social Media}

According to Hegel, human desires and social relations clash since the beginning of humanity and when two people want the same thing, they want their power to be recognized by the other. To him, the fundamental desire of people is to be recognized. Therefore, one wants others to give one a value that distinguishes one from them. In this context, when one is recognized by others as an autonomous individual, one gains personal awareness. Hegel defines this autonomy process with the master-slave dialectic, in which the latter recognizes former for fear of harm or death. The slave recognizes himself as a slave because he recognizes the other as his master (Nietzsche, 1997: 169). Contrary to the master, the slave does not develop personal awareness, and therefore, he cares about what his master thinks and depends on him. This is the basis of the master - slave dialectic (Kojeve, 2000). The slave has no autonomy and allows his master to mold him. The slave evaluates himself from the eyes of the master.

The desire for recognition and dependency defined by Hegel is the fundamental dynamic of the master-slave dialectic. A consciousness is in a game of constant exchange with other consciousnesses. It first gives itself to the other consciousness and waits to take it back. This game turns into a constant exchange, where the consciousness first becomes the other and then becomes identical to it by eliminating the other. However, the consciousness is transformed into the other consciousness, and therefore, it becomes objectified by losing its subjectivity. In order to regain its uniqueness, the consciousness seeks to find a way to be subjective again by eliminating the consciousness objected by the other. Independent and integral, consciousness seeks ways to reach a certain point of peace. Hegel argues that some consciousness do not like this uncertainty, and therefore, tend to risk their lives by avoiding this equal and mutual relationship to expose themselves as they know it. This point, where consciousness runs the risk of extinction by revealing everything that it has, is the point where it will be confident and find peace. Hegel states that the consciousness that shows this courage to be recognized belongs to the master while the other which withdraws out of fear belongs to the slave (Kojeve, 2000).

According to Hegel, the master ignores the slave and does not even regard him as an enemy, and therefore, the latter is filled with resentment against the former (Nietzsche, 1998: 40-43; Deluze, 1989: 117). This resentment creates a sense of enmity in the slave against the master who defines himself as a noble, good and moral, and the slave as bad and immoral. This enmity allows the slave to rise up against the master and seize the authority and good morals from him.

With social media, the influential masters (artists, athletes, scientists etc.) who had previously been inaccessible have now become accessible. The public, that had been turned into passive slaves by the mainstream media, have now become active users and pursued the desire to regain authority. This has given the people that have been standardized and banalized by modernism the opportunity 
to take back autonomy and feel worthy of themselves. However, this does not work out the same for everybody and leads to the emergence of unfavorable situations such as ignorance and lynching.

\section{Narcissism in Social Media}

Users have become more visible thanks to social media which has provided a sense of freedom and easy access to everything and everyone. They feel the need to thrust themselves to the forefront with the content they share and comments they make. Users with narcissistic tendencies who have little knowledge about any subject feed their false selves by criticizing experts and trying to humiliate them and even lynching them. They demonstrate this behavioral disorder in order to receive praise and support from other users, to belong to a group and to have followers and to see themselves unique, important and valuable.

Since Twitter is a social platform which is mostly used to share textual information rather than visuals, this study examined some popular Twitter comments using nonparticipant netnography methods and Vandijk's critical discourse analysis.

- Ali Türkşen, who was the Marine Staff Colonel that planted a Turkish flag on one of Kardak islets during the Imia-Kardak crisis of 1996, made a comment on Twitter on the photo of a soldier. However, a user insulted him and told him that he was a good-for-nothing who bought out his military service and knew nothing about military service. This user exhibited an example of a Dunning-Kruger syndrome because he/she did not do any research on who he/she was addressing and made use of the power of social media which makes everyone and everything accessible because of shifting authority. In psychical world, person couldn't dare to speak to a commander this way. At the same time social media makes users feel unreachable, untraceable and untouchable because of anonymous identities.

- Engin Alan, who was a Lieutenant general that served in the Turkish Cyprus Peace Operation of 1974, made a comment on the military operation against Syria. A user exhibited narcissistic behavior and told Engin Alan that he was an ignorant lieutenant general who knew nothing about psychological military operations.

- Bilge Demirköz, a CERN physicist and Associate Professor, made a comment about his field. A user suffering from Dunning-Kruger syndrome said to her "I think you'd better check your facts there." This user judges a scientist who studies at prestigious science center without getting enough knowledge about the issue. the situation makes the user ridiculed. And other users mock him. False self causes this situation. The user tries to feel important and to seem he is like intellectual person. And he wants to be appreciated by twitter users and a part of the prominent group. Because twitter users generally are consisted intellectual, well educated person who contains such as journalist, academician, writer, politician, artist

- Mahfi Eğilmez gave lectures on political economy at university, worked as a Finance Inspector for many years, as the Chairman of the Board of Directors of Garanti Bank and as an Undersecretariat of foreign trade. He shared something about economic indicators on Twitter. The comment of a user was also an example of narcissistic behavior that manifested itself as Dunning-Kruger syndrome.

- Professor Dr. Gaye Usluer shared something on Twitter concerning her discomfort about the university she worked for. A user said, "you are just a worker, do you think they would bother to consult you for things?" This is also an example to the courage of ignorance.

- Posts and comments containing insults and cusswords about such valuable scientists as illber Ortaylı, Halil İnalcık and Oktay Sinanoğlu are also a sign of narcissism.

We see above samples that users can easly reach to, criticize, question and call person who is authority of specific issue to account without has enough knowledge because of shifting authority on social media. This disdain and cynical attitude is towards all kinds of professions.

- The comment "What a stitch! You'd think he saved the world!" to a post about a doctor's medical intervention

- The comment "All it takes is 100 drugs to memorize, then I can do this job without having to go to med school for 6 years" to a news piece about doctors' field selection 
With the spread of social media, there is a serious increase in violence to the doctor, the teacher and the academician. Users encourage each other and hate speech reaches large masses through social media. The anger that develops and feeds as a result of unhealthy evaluations with ignorant courage, false self, narcissism and half-negative information causes the hatred, humiliation, humiliation and violence against certain individuals, groups or professions. Such comments disclose the narcissistic symptoms of the courage of ignorance. Encouraging such comments sometimes cause the transfer of acts of humiliation and violence from social media to the real world.

\section{Conclusion}

In the physical world, it is not to reach celebrities such as politicians, sportsmen, singer, actors. But social media makes possible to reach and interfere every people by providing communicate people who even if you live on the other side of the world. In the physical world, people who feel ordinary, worthless and unimportant make comments to every share especially celebrities post to feel special for belonging their group.

In the context of Hegel's dialectic of master-slave, this accessibility and accountability offered by social media also causes the displacement of the authority. however, this change in authority may cause humiliation and even lynch. because the shifting authority is not healthy.

User don't need to research or question any information they learn from social media or their social circle. They judge anyone even who authority of the subject with enough knowledge because of Dunning-Kruger syndrome. Mostly narcissism underlies this syndrome. Mostly narcissism underlies this syndrome. Narcissism occurs first stage of childhood. if parents don't let child creates your real self, child behave with false self. False self turns to narcissism in following time. Narcissist person has extreme manner, attitude and behaviors. Especially social media feeds narcissism.

People who have narcissism because of the false self are not always make a fool of oneself. The people feel themselves authority about any issue without get enough information and they drive their selves making comment and criticism even judging any person on social media. Sometimes they cause to the lynch trigger and mobilize the masses with the ignorant courage on social media.

Mental health impaired individuals not only disrupt their lives and relationships, but they also affect the whole society through their bad behavior towards healthy individuals. In order to establish healthy personal and social relations, the state needs to be provided through trainings prepared for parents. At this point, it is necessary to teach social media literacy to children from primary school, who not accept the truth every information from social media without questioning and to be informed about the people who are subject to lynch before making any criticism. However, the most important point is the education that should be given to parents in raising children. The training of parents to provide adequate physiological and psychological support to the child in the first three stages of selfdevelopment will ensure the development of healthy individuals.

\section{References}

[1] Akhtar, S. (1989). Narcissistic Personality Disorder. Descriptive Features And Differential Diagniosis. Psychiatr Clin North Am 12.

[2] Deleuze, G. (1989), Nietzsche and Philosophy. (. Hugh Tomlinson Transl.). New York: The Athlone Press.

[3] Karaaziz, M.\& Atak, İ. A. (2013). Narsisizm ve Narsisizmle İlgili Araştırmalar Üzerine Bir Gözden Geçirme. Nesne Psikoloji Dergisi (Npd). 2, 44-59.

[4] Kernberg, O. (2012). Sınır Durumlar ve Patolojik Narsisizm. (M. Atalay, Çev). İstanbul: Metis Yayınları.

[5] Kohut, H. (1971). Kendiliğin Çözümlenmesi. (C. Atbaşoğlu, B. Büyükkal, C. İşcan Çev.). İstanbul: Metis Yayınları

[6] Kohut, H.(1977). Kendiliğin Yeniden Yapılanması. (O. Cebeci, Çev.). İstanbul: Metis Yayınları.

[7] Kojève, A. (2000). Hegel Felsefesine Giriş. (Selahattin Hilav Çev.). İstanbul: Yapıkredi Yayınları 
[8] Kruger, J. \& Dunning, D. (1999). Unskilled and Unaware of it: How Difficulties in Recognizing One's Own Incompetence Lead to İnflated Self-Assessments. Journal of Personality and Social Psychology. Vol. 77, No. 6. ] 121-1134

[9] Nietzsche, F. (1997). İyinin Ve Kötünün Ötesinde. (Ahmet İnam Çev.). Ankara: Gündoğan Yayınları.

[10] Nietzsche, F. (1998). Ahlâkın Soykütüğü Üstüne. (Ahmet İnam Çev.). Ankara: Gündoğan Yayınları.

[11] Ozan, E., and at all. (2008). Narsistik Kişilik Bozukluğu Gelişim Süreçleri ve Yaşamı. Rchp (2), 1-2.

[12] Poundstone, W. (2017). "The Dunning-Kruger President". Https://Www.Psychologytoday.Com/Intl/Blog/Head-In-The-Cloud/201701/TheDunning-Kruger-President.

[13] Rozenblatt, S. (2002). In Defence of Self: The Relationship of Self- Esteem and Narcissim To Aggressive Behavior Long Island University, Psychology. Unpublished Doctoral Dissertation. Usa.

[14] Schlösser, T. At. All. (2013). How Unaware Are the Unskilled? Empirical Tests of the "Signal Extraction" Counterexplanation For the Dunning-Kruger Effect İn Self-Evaluation Of Performance. Journal of Economic Psychology. 39. 85-100

[15] Türk, G.D. (2017). Sosyal Medyada Linç Kültürü. Medya Çağında İletişim. (Ali Murat Kırık, Ed.). İstanbul: Çizgi Kitabevi.

[16] Türk, G.D. (2018). Humor as A Trigger of the Lynch in The Virtual World. Academic Studies In Social, Human and Administrative Sciences. (Atilla Atik, Ed.). Ankara: Gece Kitaplığı. 